\title{
AKTIVITAS SITOTOKSIK ISOLAT 5 FRAKSI ETIL ASETAT EKSTRAK PETROLEUM ETER DAUN Phaleria macrocarpa (Scheff.) Boerl. PADA TURUNAN SEL KANKER SERVIKS MANUSIA (HeLa)
}

\section{CYTOTOXIC ACTIVITY OF ISOLATE 5 OF ETHYL ACETATE FRACTION OF PETROLEUM ETHER EXTRACT OF Phaleria macrocarpa (Scheff.) Boerl. LEAVES AGAINTS HUMAN CERVICAL CANCER CELL LINES (HeLa)}

\author{
Dwi Utami \\ Fakultas Farmasi Universitas Ahmad Dahlan Yogyakarta \\ utamipurwantoro@yahoo.com
}

\section{Abstrak}

Kanker serviks merupakan penyebab kematian kedua wanita di Indonesia setelah kanker payudara. Mahkota dewa (Phaleria macrocarpa (Scheff.) Boerl) telah dikenal oleh masyarakat dan digunakan secara tradisional untuk pengobatan kanker. Ekstrak petroleum eter daun mahkota dewa menunjukkan aktivitas antiproliferasi pada sel kanker serviks manusia (HeLa) dengan $I_{50} 9 \mu \mathrm{g} / \mathrm{ml}$ (Kintoko \& Azimahtol Hawariah, 2007). Tujuan penelitian ini untuk mengetahui aktivitas sitotoksik isolat 5 fraksi etil asetat ekstrak petroleum eter terhadap turunan sel kanker serviks manusia (HeLa). Serbuk daun mahkota dewa disari menggunakan alat Soxhletasi dengan petroleum eter, kemudian difraksi dengan etil asetat hingga diperoleh fraksi etil asetat. Fraksi etil asetat dilakukan kromatografi lapis tipis preparatif dengan fase gerak heksana : etil asetat (9:1). Aktivitas sitotoksik terhadap sel HeLa ditetapkan harga $L_{50}$ melalui uji sitotoksik dengan metode perhitungan langsung. Hasil isolasi dengan kromatografi preparatif diperoleh lima isolat masing-masing dengan harga $R f: 0,05$; 0,$10 ; 0,20 ; 0,60$; dan 0,90. Aktivitas sitotoksik yang ditetapkan dari harga $L C_{50}$ isolat 5 (Rf: 0,90) sebesar 123,60 $\mu \mathrm{g} / \mathrm{ml}$.

Kata kunci : Isolat 5, Phaleria macrocarpa (Scheff.) Boerl, sitotoksik, sel HeLa, etroleum eter 


\section{Abstract}

Cervical cancer is a malignant tumor in cervix which is occupy the second possition that cause the death of Indonesia's women under the breast cancer. One of the traditional medicine that can be used to cure cancer is Phaleria macrocarpa (Scheff.)Boerl leaves. The petroleum eter extract of Phaleria macrocarpa (Scheff.)Boerl leaves has antiproliferation activity againts cervical cancer cell lines (HeLa) with $I_{50} 9 \mu \mathrm{g} / \mathrm{ml}$ (Kintoko \& Azimahtol Hawariah, 2007). This research was aimed to detect cytotoxic activity of isolate 5 of ethyl acetate fraction of petroleum ether extract of Phaleria macrocarpa (Scheff.)Boerl leaves againts HeLa cell lines. Initially, the powder of Phaleria macrocarpa (Scheff.)Boerl was extracted using Soxhlet apparatus with petroleum ether. The extracts was concentrated and partitioned until ethyl acetate fraction was obtained. The fraction of ethyl acetate was isolated using Preparative Thin Layer Chromatography on silica gel $F_{254}$ as stationary phase and n-hexane : ethyl acetate $(9: 1)$ as mobile phase. Cytotoxic activity against HeLa cell lines was determinated by $L C_{50}$ value by direct counting. The isolation by preparative thin layer chromatography resulted five isolate on $R f$ value : 0,$05 ; 0,10 ; 0,20 ; 0,60$; and 0,90. The $L C_{50}$ values of isolate 5 (Rf: 0,90) was $123,60 \mu \mathrm{g} / \mathrm{ml}$.

Key words : Isolate 5,Phaleria macrocarpa (Scheff.) Boerl, cytotoxic, HeLa cell lines, petroleum ether

\section{PENDAHULUAN}

Kanker merupakan penyakit degeneratif yang dicirikan dengan keadaan sel yang tumbuh secara terus menerus tanpa kontrol dan mempunyai kemampuan untuk menyebar (bermetastasis) ke jaringan lain secara patologi (Azimahtol Hawariah, 1998). Kanker menjadi masalah utama kesehatan di seluruh dunia dan merupakan penyakit pembunuh terbesar kedua setelah kardiovaskuler. Menurut laporan WHO tahun 2002, terdapat lebih dari 10 juta kasus kanker per tahun di dunia (Surh, 2003). Di Indonesia, penyakit kanker menjadi penyebab kematian keenam (Siswono, 2005). Dari tahun ke tahun penderita penyakit kanker jumlahnya terus meningkat termasuk di Indo- nesia dimana peningkatannya mencapai 190 ribu penderita kanker baru per tahun (Mariono dkk., 2002).

Di antara jenis kanker pada wanita, kanker leher rahim (serviks) merupakan jenis kanker maligna yang paling sering menyerang wanita, khususnya di negara-negara berkembang (Cronje, 2004) dengan jumlah penderita sebanyak 40 orang setiap 100.000 orang. Jumlah pengidap kanker serviks di Indonesia diperkirakan antara 25-40 orang penderita setiap 100.000 orang per tahun (A. de Boer dkk, 2004).

Terapi konvensional yang umum dilakukan pada penyakit kanker serviks antara lain dengan pembedahan, kemo- 
terapi dan radioterapi (Apantaku, 2002). Namun terapi pembedahan tidak dapat dilakukan khususnya pada sel kanker yang telah menyebar (metastasis), sedangkan kemoterapi dan radiasi dapat menimbulkan efek samping meskipun kemoterapi mampu mengeluarkan keseluruhan sel-sel tumor (Azimahtol Hawariah, 1998).

Kegagalan dalam kemoterapi ini biasanya berkaitan dengan kegagalan agen antikanker tersebut untuk menginduksi kematian sel kanker secara terprogram (apoptosis) (Fisher, 1994). Karena itu, usaha pencarian agen kemoterapi baru yang mampu menginduksi kematian sel kanker secara apoptosis dengan memberikan efek samping minimum sangat diperlukan dalam terapi kanker serviks, yaitu dengan mengembangkan senyawa dari bahan alami sebagai agen kemoterapi.

Mahkota dewa telah dikenal oleh masyarakat dan digunakan secara tradisional untuk pengobatan kanker. Hasil penelitian sebelumnya menunjukkan ekstrak petroleum eter daun mahkota dewa menunjukkan aktivitas antiproliferasi pada sel kanker serviks manusia (HeLa) dengan $\mathrm{IC}_{50} 9 \mu \mathrm{g} / \mathrm{ml}$ (Kintoko \& Azimahtol Hawariah, 2007). Fraksi etil asetat ekstrak petroleum eter daun mahkota dewa mempunyai aktivitas sitotoksik terhadap sel HeLa dengan nilai $\mathrm{IC}_{50} 25,409 \mu \mathrm{g} / \mathrm{mL}$ (Sahara, 2010). Fraksi kloroform ekstrak petroleum eter daun mahkota dewa mempunyai aktivitas sitotoksik terhadap sel HeLa dengan nilai $\mathrm{IC}_{50} 71,83 \mu \mathrm{g} / \mathrm{mL}$ (Kurniawati, 2010). Fraksi n-heksan ekstrak petroleum eter daun mahkota dewa mempunyai aktivitas sitotoksik terhadap sel $\mathrm{HeLa}$ dengan nilai $\mathrm{IC}_{50}$
209,196 $\mu \mathrm{g} / \mathrm{mL}$ (Maulida, 2010). Fraksi metanol-air ekstrak petroleum eter daun mahkota dewa mempunyai aktivitas sitotoksik terhadap sel HeLa dengan nilai $\mathrm{IC}_{50} \quad 431,635 \mu \mathrm{g} / \mathrm{mL}$ (Pratama, 2010).

Target utama terapi kanker secara umum adalah dengan menghambat pertumbuhan sel kanker tersebut melalui induksi proses kematian sel secara apoptosis. Karena itu, diperlukan penelitian lanjut untuk mengisolasi komponen aktif dalam ekstrak petroleum eter daun mahkota dewa dan menguji aktivitas sitotoksiknya pada sel kanker serviks manusia (HeLa).

\section{METODE PENELITIAN}

\section{Bahan}

Bahan utama penelitian ini adalah serbuk kering daun mahkota dewa. Bahan kimia yang diperlukan seperti pelarut untuk ekstraksi, fraksinasi, dan isolasi adalah petroleum eter, etil asetat derajat teknis dan pro analysis, aquadest dan silika gel $\mathrm{F}_{254}$ yang diperoleh dari Laboratorium Farmakognosi Fitokimia UAD. Sel HeLa, sel Vero, media DMEM (Dulbecco's modification of Eagle medium), DMSO, PBS (Phospat Buffered Saline), PenisillinStreptomisin 2\%, Fungison 0,5\%, FBS (Fetal bovine serum) 10\%, Trypsin-EDTA $0,25 \%$ dalam PBS, SDS (Sodium dodecyl sulfat) $10 \%$ dalam $\mathrm{HCl}$ $0,01 \mathrm{~N}, \mathrm{NaHCO}_{3}$ teknis dan HEPES (N-2-hydroxyethil piperazin-N-2ethane sulfonic acid) teknis, dan tripan blue. 


\begin{abstract}
Alat
Alat-alat yang digunakan adalah timbangan analitik, gelas ukur, gelas beker, alat sokhlet, kertas saring, vaccum rota evaporator, penangas air, cawan porselin pengaduk, plastik, karet pengikat, dan almari es, corong pisah, corong buchner, flakon dan kertas saring, autoclave, incubator $\mathrm{CO}_{2}$, lampu $\mathrm{UV}$, laminar air flow cabinet, tissue culture flask, tabung conical, microplate 96 sumuran, haemocytometer, microplate 24 sumuran (Nunclone), tissue culture flask (Nunclone), neraca elektrik (Sartorius), mikropipet (Gilson), cover slip, cover glass, mikroskop fluoresense, cell counter, ELISA reader, magnetic stirrer, mikroskop, pipet, neraca analitik, kamera digital, dan lemari es.
\end{abstract}

\section{Jalannya Penelitian}

1. Identifikasi Daun Mahkota Dewa (Phaleria macrocarpa (Scheff) Boerl)

Tanaman Daun Mahkota Dewa (Phaleria macrocarpa (Scheff) Boerl) yang akan digunakan dalam penelitian ini terlebih dahulu dilakukan identifikasi untuk memastikan kebenarannya. Identifikasi dilakukan di Laboratorium Biologi Farmasi Fakultas Farmasi Universitas Gadjah Mada Yogyakarta.

\section{Pengumpulan bahan}

Pengambilan bahan uji daun mahkota dewa dilakukan pada bulan Maret tahun 2010 di Wates, Yogyakarta. Dalam penelitian ini digunakan daun yang masih segar dan tidak rusak. Daun dibersihkan dengan air mengalir, dikeringkan dalam oven suhu $50^{\circ} \mathrm{C}$ sampai daun mahkota dewa benar-benar kering Setelah daun mahkota dewa kering maka dilakukan penyerbukan.

3. Pembuatan ekstrak petroleum eter daun mahkota dewa (Phaleria macrocarpa (Scheff) Boerl)

Serbuk daun mahkota dewa seberat 500 gram disari dengan alat Soxhlet menggunakan pelarut petroleum eter. Pelarut yang digunakan adalah $2 \mathrm{x}$ sirkulasi dengan kecepatan sirkulasi 6-8 sirkulasi/jam. Pembuatan ekstrak kental dengan Soxhlet ini dilakukan sampai zat aktif yang terdapat dalam daun mahkota dewa habis. Apabila zat aktif habis ditandai dengan jernihnya pelarut yang digunakan. Apabila filtrat telah didapatkan maka filtrat dimasukkan kedalam vaccum rota evaporator kemudian diuapkan pelarutnya sampai pelarutnya tidak menetes lagi. Penggunaan vaccum rota evaporator pada suhu $60-70{ }^{\circ} \mathrm{C}$ dan 1,5 putaran. Ekstrak kental yang diperoleh ditimbang dan dihitung rendemennya.

Rendemen $=\frac{\text { Bobot ekstrak kental } \times 100 \%}{\text { Bobot ampas kering daun mahkota dewa }}$

4. Pembuatan fraksi etil asetat daun mahkota dewa (Phaleria macrocarpa (Scheff) Boerl)

Ekstrak kental yang diperoleh dilarutkan dalam etil asetat kemudian dilakukan fraksinasi dengan air, kemudian digojog di dalam corong pisah lalu didiamkan selama 24 jam agar fraksi etil asetat dan fraksi air terpisah sempurna. Setelah didiamkan selama 24 jam selanjutnya fraksi air beserta endapanendapan yang ada didalamnya dikeluarkan. Hasil fraksi etil asetat disaring menggunakan corong buchner 
agar penyaringan lebih sempurna dan endapan yang ada didalamya benarbenar terpisahkan. Fraksi etil asetat yang didapat disimpan di lemari es.

5. Pembuatan isolat dari fraksi etil asetat daun mahkota dewa (Phaleria macrocarpa (Scheff) Boerl)

Fraksi etil asetat yang telah didapatkan dipekatkan di lemari asam, kemudian diambil dengan pipa kapiler secukupnya dan ditotolkan pada plat KLT terlebih dahulu telah dipersiapkan. Kemudian ditunggu beberapa saat sampai pita kering. Setelah itu dimasukkan ke chamber yang sudah diberi fase gerak berupa heksan:etil asetat (9:1). Elusi sampai batas yang telah ditentukan. Apabila elusi telah selesai dilakukan, maka segera dikeringkan di suhu kamar. Silica gel $60 \mathrm{GF}_{254}$ dikerok sesuai isolat yang diinginkan. Isolat tersebut digunakan untuk uji sitotoksik terhadap sel HeLa. Isolat yang terkumpul dimasukkan dalam alat Kromatografi Vakum Cair. Serbuk silika dialirkan dengan kloroform : metanol dengan perbandingan 1:1. Pelarut dialirkan hingga bubur silica menjadi berwarna putih kembali. Isolat yang diperoleh kemudian dilanjutkan uji skrining sitotoksisitas pada cell line HeLa.

\section{Uji Aktivitas Sitotoksik}

Sebelum dilakukan uji sitotoksisitas, terlebih dahulu dibuat larutan stok sampel dengan cara mencampur isolat fraksi etil asetat daun mahkota dewa dengan media DMEM. Larutan stok dibuat dengan cara menimbang isolat fraksi etil asetat daun mahkota dewa kemudian ditambah DMSO atau tween sebanyak $30 \mu 1$ dan ditambahkan dengan media DMEM hingga $1000 \mu$, sehingga diperoleh konsentrasi tertentu. Dari konsentrasi larutan tersebut kemudian dibuat seri kadar dan larutan dalam berbagai kadar tersebut dapat diujikan pada sel HeLa. Pembuatan larutan uji ini dilakukan di dalam Laminar Air Flow Cabinet secara aseptis.

Sel dengan kepadatan $1 \times 10^{4} \mathrm{sel} /$ $100 \mu 1$ didistribusikan ke dalam sumuran dan diinkubasi bersama isolat fraksi etil asetat ekstrak petroleum eter daun mahkota dewa dengan 6 kadar berbeda $750 ; 375 ; 187,5 ; 93,75 ; 46,88$ dan 23,49 $\mu \mathrm{g} / \mathrm{ml}$. Selanjutnya microplate diinkubasi dalam inkubator $\mathrm{CO}_{2} 5 \%$, pada suhu $37^{\circ} \mathrm{C}$ selama $24 \mathrm{jam}$. Setelah itu media dalam sumuran di sedot habis kemudian ditambahkan tripsin-EDTA sebanyak $100 \mu \mathrm{l}$ dan dilakukan resusupensi berlahan-lahan. Setelah didiamkan 3 menit dilakukan penambahan larutan tripan blue sebanyak $100 \mu 1$. Penghitungan jumlah sel hidup dilakukan langsung pada haemocytometer.

Sebelum penggunaan haemocytometer sebagai media penghitung sel, harus dilakukan pembersihan haemocytometer dan objek glass menggunakan alkohol $70 \%$. Setelah itu ambil $10 \mu 1$ larutan suspensi yang telah ditambahkan tripan blue menggunakan pipet pasteur dan dimasukkan kedalam chamber haemocytometer.

\section{HASIL PENELITIAN DAN PEM- BAHASAN}

Hasil determinasi daun mahkota dewa adalah

$1 b-2 b-4 b-12 b-13 b-14 b-17 b-$ $18 b-19 b-20 b-21 b-22 b-23 b-24 b$ 
$-25 b-26 b-27 b-799 b-800 b-801 b-$ $802 b-803 b-804 b-805 b-806 b-$ $807 b-808 b-809 b-810 b-811 b-$ $812 b-815 b-816 b-818 b-820 b-$ $821 b-822 b-823 b-825 b-826 b-$ $829 b-830 b-831 b-832 b-833 b-$ $834 a-835 a-836 a-837 c-851 a-852 b$ $-853 \mathrm{~b}-854 \mathrm{a}-855 \mathrm{c}-856 \mathrm{~b}-857 \mathrm{~b}-$ $872 b-874 b-875 b-876 b-877 d-$ $933 b-934 a-935 b-936 b-937 a-938 c$ $-939 a-940 a-941 b-942 b$ Thymelaceaceae

1a Phaleria

1a - 2b Phaleria macrocarpa (Scheff.)

\section{5) \\ (Backer and Van Den Brink,}

Berdasarkan hasil determinasi di atas maka dapat ditarik kesimpulan bahwa tanaman yang digunakan dalam penelitian ini adalah mahkota dewa (Phaleria macrocarpa (Scheff.) Boerl).

Hasil KLT-preparatif fraksi etil asetat ekstrak petroleum eter dengan fase diam silica gel $\mathrm{GF}_{254}$ dan fase gerak.heksana : etil asetat $(9: 1)$ menghasilkan 5 pita seperti terlihat pada gambar 1.

Boerl
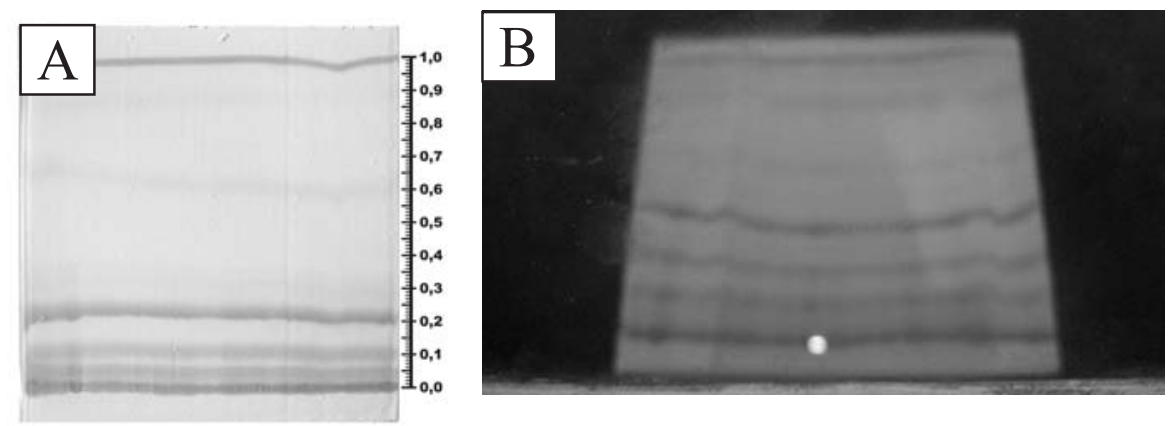

Gambar 1. Profil KLT preparatif fraksi etil asetat ekstrak petroleum eter daun mahkota dewa (Phaleria macrocarpa)

Fase diam : Silika gel GF254, Fase gerak heksana-etil asetat (9:1)

A. Sinar tampak

B. Dibawah sinar UV $254 \mathrm{~nm}$

Tabel I. Hasil KLT preparatif Fraksi Etil Asetat

\begin{tabular}{|c|c|c|l|}
\hline \multirow{2}{*}{ Nama Bercak } & \multirow{2}{*}{ Harga Rf } & \multicolumn{2}{|c|}{ Detektor } \\
\cline { 3 - 4 } & 0,05 & Visual & \multicolumn{1}{|c|}{$\mathbf{2 5 4} \mathbf{~ n m}$} \\
\hline Isolat 1 & 0,10 & Kuning & Tidak Fluoresensi biru \\
\hline Isolat 2 & 0,20 & Biru muda & Fluoresensi biru lemah \\
\hline Isolat 3 & 0,60 & Biru muda & Fluoresensi biru lemah \\
\hline Isolat 4 & 0,90 & Biru & Fluoresensi biru \\
\hline Isolat 5 & Biru tua & Fluoresensi biru \\
\hline
\end{tabular}


Pita 1 dengan harga $\mathrm{Rf}$ : 0,05 selanjutnya disebut sebagai isolat 1 , pita 2 dengan harga $\mathrm{Rf}: 0,10$ (isolat 2), pita 3 dengan harga Rf : 0,20 (isolat 3), pita 4 dengan harga $\operatorname{Rf} 0,60$ (isolat 4) dan terakhir pita 5 dengan harga Rf : 0,90 disebut sebagai isolat 5 .

Tahapan selanjutnya dari penelitian ini adalah uji aktivitas sitotoksik dari isolat 5 . Seri kadar isolat uji terhadap sel HeLa adalah 500 ; 250 ; $125 ; 62,5 ; 31,25$ dan $15,625 \mu \mathrm{g} / \mathrm{ml}$.

Tabel II. Pengaruh konsentrasi isolat 5 pada kematian sel (\%) sel Hela.

\begin{tabular}{|c|c|}
\hline Konsentrasi $(\boldsymbol{\mu g} / \mathbf{m l})$ & \% kematian sel \\
\hline 500 & $65.278 \pm 1.60$ \\
\hline 250 & $61,111 \pm 2,27$ \\
\hline 125 & $52.778 \pm 3,93$ \\
\hline 62,5 & $40,972 \pm 4,17$ \\
\hline 31,25 & $34,028 \pm 2,66$ \\
\hline 15,625 & $20,833 \pm 1,60$ \\
\hline
\end{tabular}

Berdasarkan tabel II dan grafik hubungan konsentrasi dengan \% kematian sel (Gambar 2) terlihat bahwa isolat 5 menunjukkan bersifat toksik terhadap sel HeLa yang berbanding lurus dengan kenaikan konsentrasi. Parameter yang digunakan untuk mengevaluasi potensi ketoksikan senyawa uji terhadap sel HeLa adalah $L C_{50}$. Perhitungan $L C_{50}$ menggunakan analisis probit berdasarkan pada grafik fungsi linear log konsentrasi vs nilai probit dari \% kematian sel akibat pemberian zat uji. Harga $L C_{50}$ diperoleh dengan memasukkan probit-5 ke dalam persamaan garis lurus tersebut. Berdasarkan harga $\mathrm{LC}_{50}$, terlihat bahwa isolat 5 memiliki aktivitas sitotoksik terhadap sel HeLa dengan harga $L C_{50} 123,601 \mu \mathrm{g} / \mathrm{mL}$

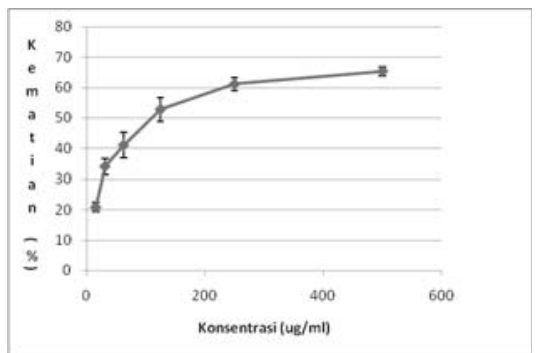

Gambar 2. Grafik hubungan konsentrasi isolat $5(\mu \mathrm{g} / \mathrm{ml})$ terhadap prosentase kematian sel HeLa

Aktivitas sitotoksik isolat 5 fraksi etil asetat ekstrak petroleum eter daun mahkota dewa dapat melalui penghambatan proliferasi sel HeLa baik melalui cell cycle delay maupun cell cycle arrest dengan pemacuan apoptosis Penghambatan ini mungkin terjadi pada penghambatan sinyal transduksi melalui penghambatan sinyal proliferasi, ataupun melalui penghambatan cell cycle progression dengan menghambat onkoprotein seperti $\mathrm{CycD}, \mathrm{CDK} 4 / 6$, dan myc, serta mampu mengaktifkan gen penekan tumor seperti $p 53$, dan memacu apoptosis dengan memodulasi ekspresi protein pengatur apoptosis seperti p53, Bcl-2, Bax, NOXA, dan sebagainya.

Penelitian sebelumnya menunjukkan bahwa asam galat sebagai salah satu komponen kimia dalam mahkota dewa menunjukkan mekanisme pemacuan apoptosis melalui up-regulasi protein pro apoptosis Bax dan mengiduksi aktivitas caspase-caspase sebagai mesin penggerak program apoptosis (Faried dkk),

Demikian pula senyawa dengan nama DLBS1425F1 E2.2 dan DLBS1425Fl yang merupakan hasil 
isolasi daun mahkota dewa dapat menghambat pertumbuhan sel kanker payudara MDA-MB-23. Harga $\mathrm{IC}_{50} \mathrm{E} 2.2$ sebesar $36.91 \mathrm{ig} / \mathrm{mL}$, sedangkan senyawa $\mathrm{Fl}$ sebesar $65.80 \mathrm{ig} / \mathrm{mL}$. Mekanisme penghambatannya dibuktikan melalui pembentukkan fragmentasi DNA, penurunan ekspresi Bcl mRNA dan kenaikkan ekspresi Bax mRNA (Tjandrawinata $\mathrm{dkk}, 2010)$.

\section{KESIMPULAN DAN SARAN}

\section{Kesimpulan}

1. Isolasi fraksi etil asetat ekstrak petroleum eter daun mahkota dewa (Phaleria macrocarpa (Scheff.) Boerl)dengan metode kromatografi lapis tipis preparatif fase gerak heksana : etil asetat (9: 1) menghasilkan 5 isolat yang belum terpurifikasi.

2. Aktivitas sitotoksik isolat 5 fraksi etil asetat ekstrak petroleum eter daun mahkota dewa (Phaleria macrocarpa (Scheff.) Boerl) adalah sebesar $123,601 \mu \mathrm{g} / \mathrm{ml}\left(\mathrm{LC}_{50}\right)$

\section{Saran}

1. Perlu dilakukan pemurnian lebih lanjut terhadap isolat hasil KLT preparatif, dengan kromatografi kolom ataupun HPLC.

2. Perlu dikaji lebih lanjut mekanisme penghambatan pertumbuhan sel HeLa secara molekuler melalui uji imunositokimia terhadap enzim, protein ataupun gen yang berperan dalam proliferasi ataupun apoptosis.

\section{DAFTAR PUSTAKA}

A. de Boer, M., A.W. Peter, L., Aziz, M.F., Siregar, B., Cornain, S., Vrede, M.A., S. Jordanova, E., Uljee, S.K. and Fleuren, G.J. 2004. Human papilomavirus type 16 E6, E7 and L1 variant in cervical cancer in Indonesia, Suriname, Netherland. Gynecology Oncol.94:488-494.

Apantaku, L.M. 2002. Breast-conseving surgery for breast cancer. American.Fam.Physician 66 (12): 2271-2278.

Azimahtol Hawariah, L.P. 1998. Kanker Payudara. Serdang: Penerbit Universiti Putra Malaysia.

Backer, C.A.D., and Bakhuizen Van Den Brink, K.R.C.Jr., 1965, Flora of Java (Spermatophytes only), Vol II, N.V.P. Noordhooff, Groningen, The Netherlands.

Cronje, H.S. 2004. Screening of cervical cancer in developing countries. Int. J. Gynecology and Obstery $\mathbf{8 4}$ : 101-108.

Faried, A., Kurnia, D., Faried, L. S., Usman, N., Miyazaki, T., Kato, H., Kuwano, H., 2006, Anticancer Effects of Gallic Acid Isolated from Indonesian Herbal Medicine Phaleria macrocarpa (Scheff.) Boerl, on Human Cancer Cell Lines : International Journal of Oncology, Padjadjaran University Faculty of Medicine, Bandung

Fisher, D.E. 1994. Apoptosis in cancer therapy: crossing the threshold. Cell 78(4): 539-542. 
Kurniawati,Anisa, 2010, Sitotoksisitas Fraksi Kloroform Ekstrak Petroleum Eter Daun Mahkota Dewa ( Phaleria Macrocarpa (Scheff.) Boerl ) terhadap Sel Hela dan Sel Vero beserta Profil Kromatografinya, Skripsi' Universitas Ahmad Dahlan, Yogyakarta

Kintoko \& Azimahtol Hawariah. 2007. Antiproliferative effect of extract of mahkota dewa [Phaleria macrocarpa (Scheff). Boerl.] on selected cancer cell line and its mode of cell death. Proceeding of the ${ }^{\text {Ist }}$ International Conference on Chemical Science, hlm. 229-231.

Mariono, S.A., Jusuf, A., Kresno, S.B. 2002. Karakteristik kandungan DNA dan aktivitas proliferasi pada kanker paru di Jakarta. Cermin Dunia Kedokteran. 127: 15-17.

Maulida, Nisa, A., 2010 Sitotoksisitas Fraksi n-Heksan Ekstrak Petroleum Eter Daun Mahkota Dewa (Phaleria Macrocarpa (Scheff.) Boerl ) terhadap Sel Hela dan Sel Vero beserta Profil Kromatografinya, Skripsi, Univer sitas Ahmad Dahlan, Yogyakarta

Pratama, Anton, 2010, Sitotoksisitas Fraksi Metanol-Air Ekstrak Petroleum Eter Daun Mahkota
Dewa ( Phaleria Macrocarpa (Scheff.) Boerl ) terhadap Sel Hela dan Sel Vero beserta Profil Kromatografinya, Skripsi, Universitas Ahmad Dahlan, Yogyakarta

Sahara, Nasa Milta, 2010, Uji Sitotoksisitas Fraksi Etil Asetat Ekstrak Petroleum Eter Daun Mahkota Dewa (Phaleria Macrocarpa (Scheff.) Boerl ) terhadap Sel Hela dan Sel Vero beserta Profil Kromatografinya, Skripsi, Universitas Ahmad Dahlan, Yogyakarta

Siswono. 2005. Setiap tahun 190 ribu penderita kanker baru. Diakses dari http://www.gizi.net [12 November 2006].

Surh, Y.J, 2003, Cancer Chemoprevention with Dietary Phytochemicals, Nature Reviews Cancer 3: 768 - 780 .

Tjandrawinata RR, Arifin PF, Tandrasasmita OM, Rahmi D, Aripin A, 2010,

DLBS1425, a Phaleria macrocarpa (Scheff.) Boerl. extract confers anti proliferative and proapoptosis effects via eicosanoid pathway, $J$. Therapy. Oncology: 8 (3) : 187201 